\title{
Differential Regulation of Synaptic Plasticity and Cerebellar Motor Learning by the C-Terminal PDZ-Binding Motif of GluR $\delta 2$
}

\author{
Wataru Kakegawa, ${ }^{1}$ Taisuke Miyazaki, ${ }^{2}$ Kyoichi Emi, ${ }^{1}$ Keiko Matsuda, ${ }^{1}$ Kazuhisa Kohda, ${ }^{1}$ Junko Motohashi, ${ }^{1}$ \\ Masayoshi Mishina, ${ }^{3}$ Shigenori Kawahara, ${ }^{4}$ Masahiko Watanabe, ${ }^{2}$ and Michisuke Yuzaki ${ }^{1}$ \\ ${ }^{1}$ Department of Physiology, School of Medicine, Keio University, Tokyo 160-8582, Japan, ${ }^{2}$ Department of Anatomy, Hokkaido University Graduate School \\ of Medicine, Sapporo 060-8638, Japan, ${ }^{3}$ Department of Molecular Neurobiology and Pharmacology, Graduate School of Medicine, and ${ }^{4}$ Laboratory of \\ Neurobiophysics, Graduate School of Pharmaceutical Sciences, University of Tokyo, Tokyo 113-0033, Japan
}

The $\delta 2$ glutamate receptor (GluR $\delta 2)$ is predominantly expressed in Purkinje cells and plays crucial roles in cerebellar functions: $G l u R \delta 2^{-1-}$ mice display ataxia and impaired motor learning. In addition, long-term depression (LTD) at parallel fiber (PF)-Purkinje cell synapses is abrogated, and synapse formation with PFs and climbing fibers (CFs) is severely disturbed in GluR $\delta 2^{-1-}$ Purkinje cells. Recently, we demonstrated that abrogated LTD was restored in GluR $\delta 2^{-1-}$ Purkinje cells by the virus-mediated expression of the wild-type GluR $\boldsymbol{\delta} 2$ transgene ( $\left.T g_{\text {wt }}\right)$ but not by that of mutant $G l u R \delta 2$ lacking the C-terminal seven residues to which several PDZ proteins bind $\left(T g_{\Delta \mathrm{CT} 7}\right)$. These results indicated that the $\mathrm{C}$ terminus of GluR $\delta 2$ conveys the signal(s) necessary for LTD. In contrast, other phenotypes of GluR $\delta 2^{-/-}$cerebellum, especially morphological abnormalities at PF and CF synapses, could not be rescued by virus-mediated transient expression. Thus, whether these phenotypes are mediated by the same signaling pathway remains unclear. To address these issues and to further delineate the function of GluR $\delta 2$ in vivo, we generated transgenic mice that expressed $T g_{\Delta \mathrm{CT} 7}$ on a $G l u R \delta 2^{-/-}$ background. Interestingly, although $\mathrm{Tg}_{\Delta \mathrm{CT7}}$ restored abnormal PF and CF synapse formation almost completely, it could not rescue abrogated LTD in GluR $\boldsymbol{\delta} 2^{-/-}$Purkinje cells. Furthermore, although the gross motor discoordination of GluR $\delta 2^{-/-}$mice was restored, the cerebellar motor learning underlying delayed eyeblink conditioning remained impaired. These results indicate that LTD induction and motor learning are regulated by signaling via the C-terminal end of GluR $\delta 2$, whereas other functions may be differentially regulated by other regions of GluR $\delta 2$.

Key words: cerebellum; LTD; glutamate receptor; PDZ domains; Purkinje cell; eyeblink

\section{Introduction}

The $\delta 2$ glutamate receptor (GluR $\delta 2$ ), a member of the ionotropic glutamate receptor (iGluR) family (Araki et al., 1993; Lomeli et al., 1993), is predominantly expressed on the postsynaptic sites of parallel fiber (PF)-Purkinje cell synapses (Landsend et al., 1997; Zhao et al., 1997) and plays indispensable roles in cerebellar functions: GluR 2 -null mice display ataxia and impaired motorrelated learning tasks such as eyeblink conditioning (Yuzaki, 2004). Detailed analyses of GluR $\delta 2$-null mice have revealed two crucial roles of GluR $\delta 2$ at PF synapses: the formation or stabilization of synaptic contacts and the control of long-term depres-

Received June 6, 2007; revised Dec. 14, 2007; accepted Dec. 16, 2007.

This work was supported by the Grant-in-Aid for the Ministry of Education, Culture, Sports, Science and Technology of Japan (W.K., M.Y.), the Takeda Science Foundation, the Keio Gijuku Academic Development Funds, and the Keio University Grant-in-Aid for the Encouragement of Young Medical Scientists (W.K.). We thank members of the Genome Information Research Center (Osaka University) for the generation of transgenic mice.

Correspondence should be addressed to Michisuke Yuzaki, Department of Physiology, Keio University School of Medicine, 35 Shinanomachi, Shinjuku-ku, Tokyo 160-8582, Japan. E-mail: myuzaki@sc.itc.keio.ac.jp.

S. Kawahara's present address: Graduate School of Science and Engineering, University of Toyama, Toyama 930-8555, Japan.

DOI:10.1523/JNEUROSCI.2553-07.2008

Copyright $\odot 2008$ Society for Neuroscience $\quad$ 0270-6474/08/281460-09\$15.00/0 sion (LTD), an elemental process underlying cerebellar motor learning. Furthermore, although wild-type Purkinje cells become innervated by single climbing fibers (CFs) by the end of the third postnatal week, adult GluRS2-null Purkinje cells remain innervated by supernumerary CFs. Despite these essential roles played by GluR $\delta 2$ in the cerebellum, the underlying mechanisms are not well understood, mainly because of the lack of specific agonists for GluR $\delta 2$.

To obtain clues to the functioning of GluR $\delta 2$ without relying on pharmacological tools, we recently exploited the "transgenic rescue" approach. We generated lines of mice that expressed mutant GluR $\delta 2$ transgenes in a GluR $\delta 2$-null background. Because a mutant $G l u R \delta 2$ transgene, in which the glutamate-binding motif conserved in iGluRs was mutated, rescued all abnormal phenotypes of GluR $\delta 2$-null mice, we concluded that GluR $\delta 2$ was unlikely to be activated by glutamate analogs in vivo (Hirai et al., 2005). Similarly, because a mutant GluR $\delta 2$ transgene, in which the ion selectively filter was mutated, rescued the phenotypes of GluR $\delta 2$-null mice, GluR $\delta 2$ was considered unlikely to function as a $\mathrm{Ca}^{2+}$-permeable channel (Kakegawa et al., 2007). We therefore hypothesize that although GluR $\delta 2$ belongs to the iGluR family, it may function as a nonionotropic receptor. Indeed, using a virus- 
mediated "rescue" approach, we recently demonstrated that abrogated LTD was restored in GluR $\delta 2$-null Purkinje cells by the transduction of the wild-type GluR $\delta 2$ transgene $\left(T g_{\mathrm{wt}}\right)$ but not by the transduction of a mutant GluR $\delta 2$ lacking the C-terminal seven residues $\left(T g_{\Delta \mathrm{CT} 7}\right)$ (Kohda et al., 2007); this region binds to several PDZ [postsynaptic density-95 (PSD-95)/Discs large/zona occludens-1) proteins such as PSD-93, synaptic scaffolding molecule (S-SCAM), protein tyrosine phosphatase PTPMEG, and delphilin (Yuzaki, 2004). These results indicate that PDZ proteins that bind to the $\mathrm{C}$ terminus of GluR $\delta 2$ may convey intracellular signals necessary for the induction of LTD. Nevertheless, whether the other abnormal phenotypes of GluRS2-null Purkinje cells, especially the morphological abnormalities at PF and CF synapses, are also mediated by the same signaling pathway remains unclear, because these phenotypes could not be rescued by the virus-mediated transient expression of the wild-type GluR $\delta 2$ transgene (Kohda et al., 2007). To address these issues and to further delineate the function of GluR $\delta 2$ in vivo, we generated transgenic mice that expressed $T g_{\Delta \mathrm{CT} 7}$ on a GluR $\delta 2$-null background. We demonstrated, for the first time, that signaling via the C-terminal end of GluR $\delta 2$ was dispensable for morphological integrity at PF and CF synapses, whereas signaling was absolutely required for the induction of LTD and motor learning, indicating that GluR $\delta 2$ may function via at least two distinct mechanisms.

\section{Materials and Methods}

All the experimental procedures involving the use of animals were approved by the Animal Resource Committee of the Keio University School of Medicine.

Animals. Mutant mice carrying the GluR $\delta 2$ transgene were generated as described previously (Hirai et al., 2005). Briefly, a mutant GluR $\delta 2$ transgene lacking the last seven amino acids at the $\mathrm{C}$ terminus $\left(T g_{\Delta \mathrm{CT} 7}\right)$ was inserted into the BamHI site of pL7AAUG. The resulting plasmids were digested with $K p n I$ and EcoRI, and the linearized L7-GluRS2 constructs were injected into fertilized eggs (Genome Information Research Center, Osaka University, Osaka, Japan). Twelve $T g_{\Delta \mathrm{CT} 7}$ founders were then bred onto a GluR $\delta 2^{-1-}$ background (termed GluR $\delta 2^{-1-} / \mathrm{Tg}_{\Delta \mathrm{CT}}$ ). Homozygous transgenic lines were established and confirmed by backcrossing with wild-type mice.

Antibodies. To detect the GluR $\delta 2$ protein, we used two kinds of rabbit polyclonal anti-GluR $\delta 2$ antibodies with distinct epitopes (see Fig. $1 \mathrm{~A}$ ): an anti-GluR $\delta 2(837-888)$ antibody (Takayama et al., 1995) that recognizes the 52 amino acids of the C-terminal juxtamembrane segment (837-888 amino acids); and an anti-GluR $\delta 2(973-992)$ antibody (Chemicon, Temecula, CA) that recognizes the 20 amino acids of the most C-terminal region (973-992 amino acids).

Immunohistochemistry. Under deep anesthesia with an intraperitoneal injection of pentobarbital, adult mice (over 4 weeks of age) were fixed by cardiac perfusion with $4 \%$ paraformaldehyde in $0.1 \mathrm{~m}$ sodium phosphate buffer (PBS, pH 7.4), and the cerebellum was removed and postfixed by $4 \%$ paraformaldehyde in PBS overnight. After rinsing the specimens with PBS, parasagittal slices $(100 \mu \mathrm{m})$ were prepared using a microslicer (DTK-2000; D.S.K., Kyoto, Japan) and were permeabilized using $0.4 \%$ Triton X-100 (Sigma, St. Louis, MO) in PBS containing 0.2\% normal goat serum and $0.2 \%$ bovine serum albumin for $6 \mathrm{~h}$ at $4^{\circ} \mathrm{C}$. Immunohistochemical staining was performed using anti-GluR $\delta 2$ antibodies (1:500) at $4^{\circ} \mathrm{C}$ followed by incubation with Alexa546-conjugated secondary antibodies (diluted 1:1000; Invitrogen, Eugene, OR). The stained slices were viewed using a confocal laser-scanning microscope (Fluoview; Olympus Optical, Tokyo, Japan).

Immunoblotting. To examine the total expression level of GluR $\delta 2$, whole cerebella were homogenized in lysis buffer ( $50 \mathrm{~mm} \mathrm{NaF}, 1 \% \mathrm{NP}-$ 40, $20 \mathrm{~mm}$ EDTA, 0.1\% SDS, $50 \mathrm{~mm}$ Tris- $\mathrm{HCl}, \mathrm{pH}$ 8.0) containing a protease inhibitor mixture (Calbiochem, La Jolla, CA). To prepare the postsynaptic density (PSD) fraction, whole cerebella were homogenized in buffer containing $0.32 \mathrm{~m}$ sucrose and $5 \mathrm{~mm}$ HEPES, $\mathrm{pH}$ 7.5, and the nuclear fraction was removed by centrifugation at $800 \times g$ for $5 \mathrm{~min}$. The supernatant was centrifuged at $12,000 \times g$ for $15 \mathrm{~min}$ at $4^{\circ} \mathrm{C}$, and the pellet was resuspended in $1 \%$ Triton X-100/PBS so that the protein concentration became $1 \mathrm{mg} / \mathrm{ml}$. After incubation for $1 \mathrm{~h}$ at $4^{\circ} \mathrm{C}$, the insoluble "PSD fraction" was precipitated by centrifugation at $100,000 \times g$ for 30 min at $4^{\circ} \mathrm{C}$. After washing with $1 \%$ Triton X-100/PBS for 30 min, the PSD fraction was solubilized in the SDS-PAGE sample buffer. The total homogenates and the PSD fractions were analyzed by immunoblotting with anti-GluR $\delta 2(837-888)$ antibodies. The specificity of the anti-GluR $\delta 2$ antibodies was established using Western blots, and the bound immunoglobulin was detected using an enhanced chemiluminescence system (GE Healthcare, Piscataway, NJ). The fluorescence was quantified using an image analyzer (LAS-3000; Fujifilm, Tokyo, Japan).

Electron microscopy. Conventional electron microscopy (EM) analysis and postembedding immunogold EM analysis were performed as described previously (Fukaya et al., 2003; Hirai et al., 2005). The number of gold particles, synapses, and lengths of the PSD and active zone were measured on scanned electron micrographs using MetaMorph software (Molecular Devices, Sunnyvale, CA).

Behavioral analysis. Walking footprint pattern analysis and the rotorrod test were performed as described previously (Hirai et al., 2005; Kakegawa et al., 2007). The eyeblink conditioning test was also performed as described previously (Kishimoto et al., 2001). Briefly, male mice (over $8-10$ weeks of age) were surgically implanted with four Teflon-coated stainless steel wires (A-M Systems, Carlsborg, WA) under the left eyelid to record electromyographic activity and to deliver an electric shock. A periorbital shock (100 Hz square pulses for $100 \mathrm{~ms}$ ) was applied as an unconditioned stimulus (US), and a tone ( $1.0 \mathrm{kHz}, 85 \mathrm{~dB}$ for $350 \mathrm{~ms}$ ) was used as a conditioning stimulus (CS). In the delay paradigm, the US overlapped the CS in time such that the two stimuli terminated simultaneously (see diagram in Fig. $7 C$ ). To calculate the conditioned response (CR), the electromyogram amplitude was analyzed $200 \mathrm{~ms}$ before the US onset in the CS-US paired trials. The spontaneous eyeblink frequency, which was recorded for $2 \mathrm{~d}$ before the acquisition phase, was measured in 100 nonstimulus trials.

Electrophysiology. Parasagittal cerebellar slices $(200 \mu \mathrm{m})$ were prepared from GluR $\delta 2^{-1-}$ and each transgenic mouse (postnatal day 2438), as described previously (Hirai et al., 2005; Kakegawa et al., 2007). Whole-cell recordings were made from visually identified Purkinje cells using a $60 \times$ water-immersion objective attached to an upright microscope (BX51WI; Olympus Optical) at room temperature. The resistance of patch pipettes was $3-5 \mathrm{M} \Omega$ when filled with an intracellular solution of the following composition (in $\mathrm{mM}$ ): 65 Cs-methanesulfonate, 65 K-gluconate, 20 HEPES, $10 \mathrm{KCl}, 1 \mathrm{MgCl}_{2}, 4 \mathrm{Na}_{2} \mathrm{ATP}, 1 \mathrm{Na}_{2} \mathrm{GTP}, 5$ sucrose, and 0.4 EGTA, pH 7.25 (295 mOsm $/ \mathrm{kg})$. The solution used for slice storage and recording consisted of the following (in mM): $125 \mathrm{NaCl}$, $2.5 \mathrm{KCl}, 2 \mathrm{CaCl}_{2}, 1 \mathrm{MgCl}_{2}, 1.25 \mathrm{NaH}_{2} \mathrm{PO}_{4}, 26 \mathrm{NaHCO}_{3}$, and 10 D-glucose, bubbled continuously with a mixture of $95 \% \mathrm{O}_{2}$ and $5 \% \mathrm{CO}_{2}$. Picrotoxin (100 $\mu \mathrm{M}$; Sigma) was always added to the saline to block inhibitory synaptic transmission. The EPSCs were recorded using an Axopatch 200B amplifier (Molecular Devices), and the pClamp system (version 9.2; Molecular Devices) was used for data acquisition and analysis. The signals were filtered at $1 \mathrm{kHz}$ and digitized at $4 \mathrm{kHz}$.

To evoke EPSCs derived from CF (CF-EPSCs) and PF (PF-EPSCs) inputs onto Purkinje cells, square pulses were applied through a stimulating electrode placed on the granular layer and the molecular layer ( $\sim 50 \mu \mathrm{m}$ away from the pial surface), respectively. The selective stimulation of CFs and PFs was confirmed by the paired-pulse depression and paired-pulse facilitation (PPF) of EPSC amplitudes at a $50 \mathrm{~ms}$ interstimulus interval (ISI), respectively. To search for multiple CFs innervating the recorded Purkinje cell, the stimulating electrode was moved systematically in the granular layer, and the stimulus intensity was gradually increased at each stimulation site (pulse width, $50 \mu \mathrm{s}$; strength, 0-200 $\mu \mathrm{A})$. For the LTD sessions, PF-EPSCs were recorded successively at a frequency of $0.1 \mathrm{~Hz}$ from Purkinje cells clamped at $-80 \mathrm{mV}$. After a stable PF-EPSC amplitude had been observed for at least $10 \mathrm{~min}$, a conjunctive stimulation that consisted of 30 single PF stimuli together with a $200 \mathrm{~ms}$ depolarizing pulse from a holding potential of -60 to $+20 \mathrm{mV}$ was applied for LTD induction. Access resistances were monitored every 
$10 \mathrm{~s}$ by measuring the peak currents in response to $2 \mathrm{mV}, 50 \mathrm{~ms}$ hyperpolarizing steps throughout the experiments; the measurements were discarded if the resistance changed by $>20 \%$ of its original value. The normalized EPSC amplitude on the ordinate represents the EPSC amplitude for the average of six traces for $1 \mathrm{~min}$ divided by that of the average of six traces for $1 \mathrm{~min}$ immediately before the conjunctive stimulation.

Data analysis and statistics. The results are presented as the means \pm SEM, and the statistical significance was defined as $p<0.05$, by using the unpaired Student's $t$ test, the one-way ANOVA followed by Bonferroni's multiple comparison test, and multiple $t$ test with Bonferroni's correction.

\section{Results}

Generation of $G l u R \delta 2^{-/-} / \operatorname{Tg}_{\Delta \mathrm{CT} 7}$ rescue mice Previously, we used the Purkinje cell-specific L7 promoter (Hirai et al., 2005) to drive the expression of a wild-type GluR $\delta 2$ transgene $\left(T g_{w t}\right)$ and obtained a transgenic rescue line called $G l u R \delta 2^{-/} / T g_{\text {wt }}$ by breeding transgenic mice onto a GluR $\delta 2^{-1-}$ background (Hirai et al., 2005; Kakegawa et al., 2007). Similarly, to examine the function regulated by the $\mathrm{C}$ terminus of GluR $\delta 2$, we generated a GluR $\delta 2^{-/-}$/ $T g_{\Delta \mathrm{CT} 7}$ line that expressed a mutant GluR $\delta 2$ transgene lacking the $\mathrm{C}$-terminal seven amino acids $\left(T g_{\Delta \mathrm{CT} 7}\right)$; this region is known to bind to PSD-93, S-SCAM, PTPMEG, and delphilin (Yuzaki, 2004). Both GluR $\delta 2^{-1-} / T g_{\mathrm{wt}}$ and GluR $\delta 2^{-/-} / \mathrm{Tg}_{\Delta \mathrm{CT} 7}$ lines were bred to homozygosity with regard to each transgene. We confirmed that $\mathrm{Tg}_{\Delta \mathrm{CT} 7}$ was properly inserted into the genome by sequencing the genomic DNA (Fig. $1 B$ ). In addition, we confirmed the expression of the transgenic protein products using an immunohistochemical analysis with anti-GluR 2 2(837-888) antibody, which recognizes the $\mathrm{C}$-terminal juxtamembrane segment (Fig. $1 A$ ), a region common to both $\mathrm{Tg}_{\mathrm{wt}}$ and $\mathrm{Tg}_{\Delta \mathrm{CT}}$ proteins (Fig. $1 C$ ). Both $\mathrm{Tg}_{\mathrm{wt}}$ and $\mathrm{Tg}_{\Delta \mathrm{CT} 7}$ were selectively expressed in the cerebellum (supplemental Fig. S1, available at www.jneurosci.org as supplemental material). In contrast, the anti-GluR $\delta 2(973-992)$ antibody, which recognizes the C-terminal end of GluR $\delta 2$ (Fig. 1A), failed to reveal immunoreactivity in the GluR $\delta 2^{-/-} / T g_{\Delta \mathrm{CT} 7}$ cerebellum (Fig. 1C). To quantify the expression level of transgenes, band intensities of the GluR $\delta 2$ protein in $10 \mu \mathrm{g}$ of $G l u R \delta 2^{-/-} / T g_{\mathrm{wt}}$ or GluR $\delta 2^{-/-} / \mathrm{Tg}_{\Delta \mathrm{CT} 7}$ cerebellar cell lysates were compared with those in various amounts of wild-type cerebellar cell lysates by immunoblot analysis using anti-GluR $\delta 2(837-888)$ antibody. We found that the expression levels of $\mathrm{Tg}_{\mathrm{wt}}$ and $\mathrm{Tg}_{\Delta \mathrm{CT} 7}$ proteins were $\sim 20$ and $40 \%$ of those of endogenous GluR $\delta 2$ protein in wild-type $\left(G l u R \delta 2^{+/+}\right)$cerebellum, respectively (Fig. $1 D$ ). Indeed, hemizygous GluR $\delta 2^{-/-} / \mathrm{Tg}_{\Delta \mathrm{CT} 7}$ mice, which contained half the number of $T g_{\Delta \mathrm{CT} 7}$ copies, and homozygous GluR $\delta 2^{-/}$ $-/ T g_{\mathrm{wt}}$ expressed nearly equivalent amount of transgenic GluR $\delta 2$ proteins (Fig. 1D).

C

Ab 2

anti-

GluRס2

(973-992)

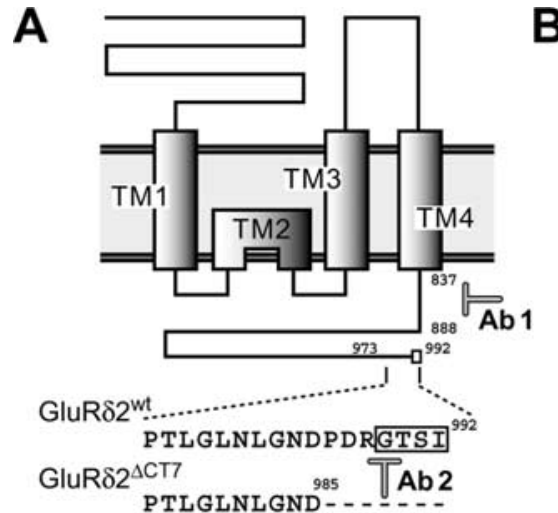

B GluR $\delta 2^{-1-} / T g_{\mathrm{wt}}$

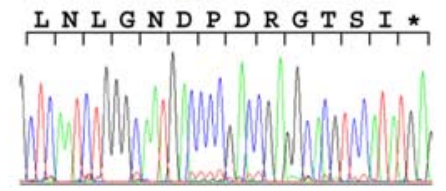

GluR $\delta 2^{-/-} / T g_{\Delta \mathrm{CT} 7}$ L N L G N D *
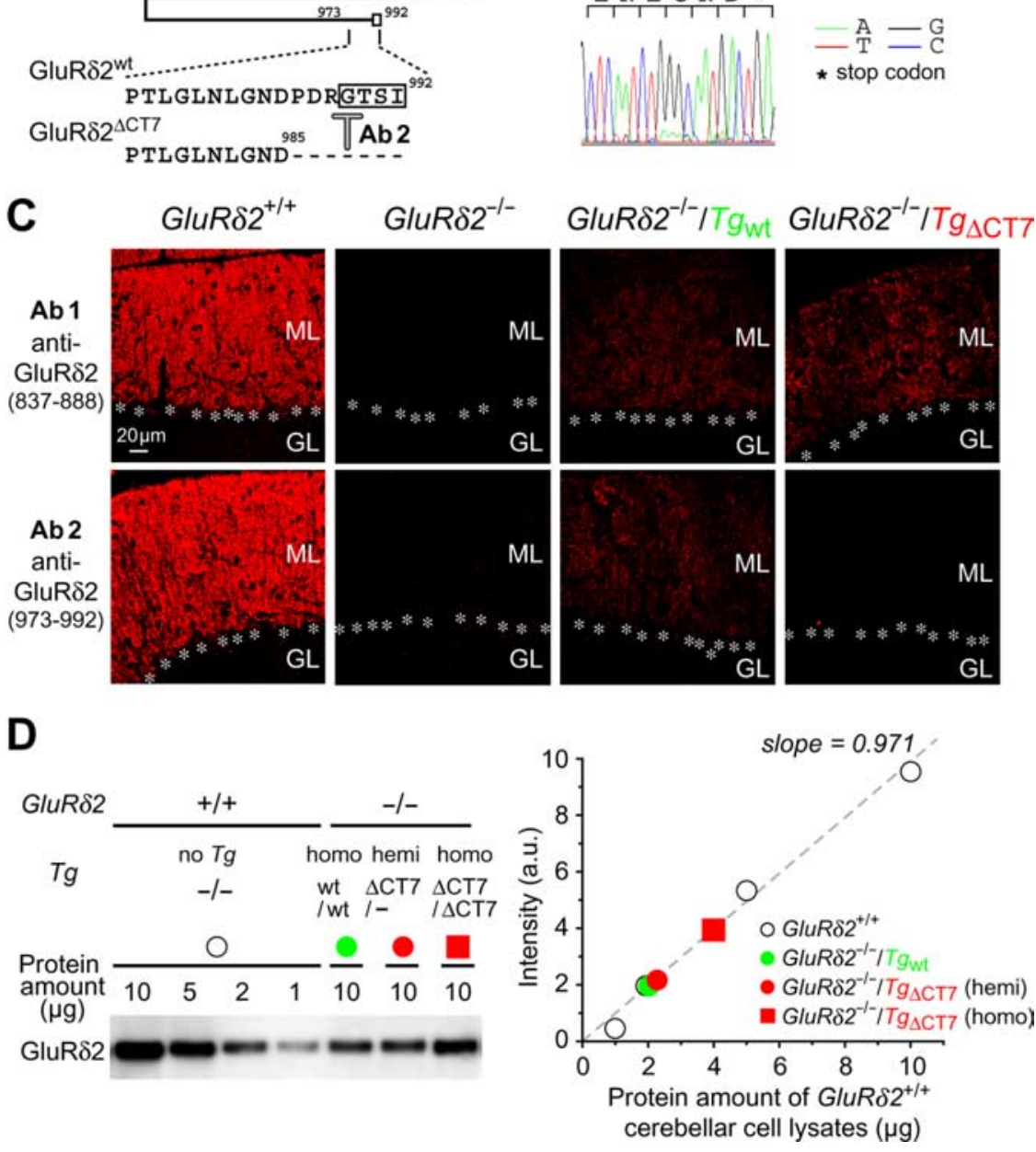

Figure 1. Characterization of GluR $\delta 2^{-/-} / T g_{\Delta C T 7}$ mice. A, Putative membrane topology of GluR $\delta 2$ and amino acid sequences of the extreme C-terminal regions. The open box surrounds the GluR $\delta 2$ PDZ-binding motif. The seven amino acids (PDRGTSI) at the end of the $C$ terminus are deleted in GluR $\delta 2^{\Delta \mathrm{CT7}}$. The 52 amino acids of the C-terminal juxtamembrane segment (837-888 amino acids) and the 20 amino acids at the end of the C-terminal region (973-992 amino acids) are epitopes against anti-GluR $\delta 2(837-888$; Ab1)-specific and anti-GluR $\delta 2(973-992 ;$ Ab2)-specific antibodies, respectively. $\boldsymbol{B}$, Representative sequence traces of genomic PCR products from GluR $\delta 2^{-/-} / T g_{\mathrm{wt}}$ and $G l u R \delta 2^{-/-} / T g_{\Delta \mathrm{CT} 7}$ mice. C, Immunofluorescence images showing GluR $\delta 2$ expression using anti-GluR $\delta 2$ (837-888) (top) and anti-GluR $\delta 2$ (973-992) (bottom)

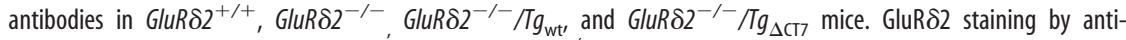
GluR $\delta 2$ (973-992) antibodies was not detectable in GluR $\delta 2^{-/-} / \mathrm{Tg}_{\Delta \mathrm{CT} 7}$ cerebella. ML, Molecular layer; GL, granular layer; asterisks, Purkinje cell soma. D, Quantitative immunoblot analysis of cerebellar lysates from each mouse. The band intensities

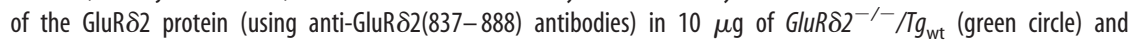
GluR $\delta 2^{-1-} / T g_{\Delta C T 7}$ [homozygotes (homo), red square; hemizygotes (hemi), red circle] cerebellar lysates were compared with those in various amounts $(10,5,2$, and $1 \mu \mathrm{g})$ of GluR $\delta 2^{+/+}$(open circles) cerebellar cell lysates (slope $=0.971$ using the linear least-squares fitting method). The $x$-axis shows the protein amount of $G / u R \delta 2^{+/+}$cerebellar cell lysates.

\section{Postsynaptic expression of $\mathrm{Tg}_{\Delta \mathrm{CT} 7}$ protein}

One of the functions of many PDZ proteins interacting with the $\mathrm{C}$ termini of membrane receptors is to anchor them at postsynaptic sites in neurons (Sheng and Sala, 2001). Thus, to examine the role of the $\mathrm{C}$ terminus in localizing GluR $\delta 2$ at synapses, we performed an immunogold EM analysis using anti-GluR $\delta 2(837-888)$ antibody. Although hemizygous GluR $\delta 2^{-/-} / \mathrm{Tg}_{\Delta \mathrm{CT} 7}$ mice and ho- 

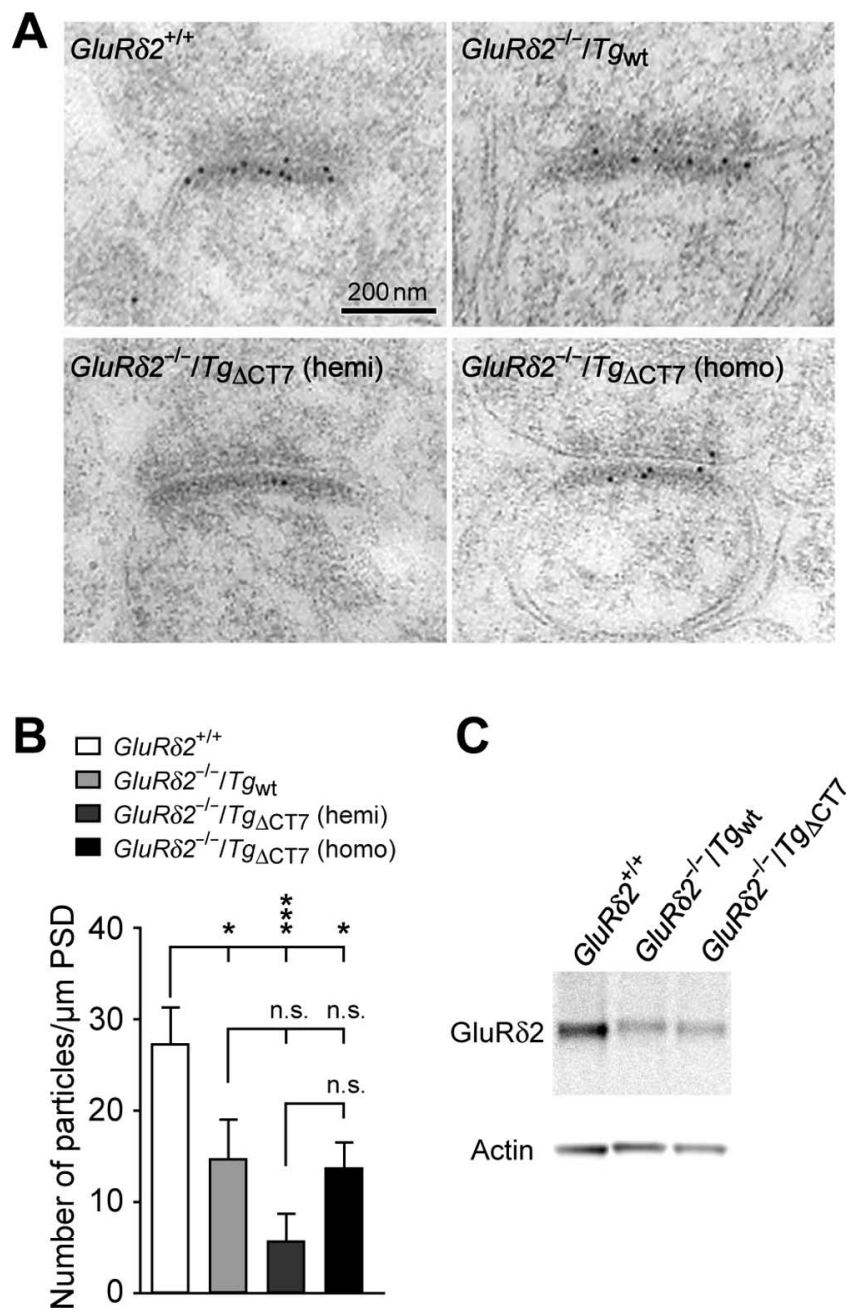

Figure 2. Localization of transgenic GluR $\delta 2$ proteins at the PSD of the PF-Purkinje cell synapses. $\boldsymbol{A}$, Representative images of immunogold electron microscopic analysis using anti-

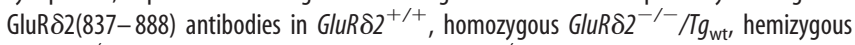
GluR $\delta 2^{-/-} / T g_{\Delta \mathrm{CT} 7}$ (hemi), and homozygous GluR $\delta 2^{-/-} / T g_{\Delta \mathrm{CT} 7}$ (homo) cerebella. The number of gold particles is correlated with the amount of GluR $\delta 2$ protein. $\boldsymbol{B}$, Histogram showing the averaged number of gold particles per $1 \mu \mathrm{m}$ PSD length. ${ }^{* * *} p<0.001$; ${ }^{*} p<0.05$. n.S., No significance. C, Representative immunoblotting data from the isolated PSD fraction of homozygous GluR $\delta 2^{-/-} / T g_{\text {wt }}$ and homozygous GluR $\delta 2^{-/-} / T g_{\Delta \mathrm{CT} 7}$ cerebellar lysates using antiGluR $\delta 2(837-888)$ antibodies.

mozygous $G l u R \delta 2^{-/-} / \mathrm{Tg}_{\mathrm{wt}}$ mice had similar transgene protein expression levels (Fig. $1 D$ ), the number of immunogold particles observed at the PSD of the PF-Purkinje cell synapses were lower in the hemizygous GluR $\delta 2^{-/-} / \operatorname{Tg}_{\Delta \mathrm{CT} 7}$ mice $(6 \pm 3$ particles $/ \mu \mathrm{m})$ than in the homozygous GluR $\delta 2^{-/-} / \mathrm{Tg}_{\mathrm{wt}}$ mice (15 \pm 4 particles/ $\mu \mathrm{m}$; one-way ANOVA followed by Bonferroni's test, $F_{(3,8)}=$ $18.58 ; p=0.094$ ) (Fig. $2 A, B)$. Nevertheless, the homozygous GluR $\delta 2^{-/-} / \operatorname{Tg}_{\Delta \mathrm{CT} 7}$ mice, which expressed twice as much transgenic protein as the homozygous GluR $\delta 2^{-/-} / T g_{\text {wt }}$ mice, exhibited a similar number of immunogold particles at the PSD (14 \pm 3 particles/ $\mu \mathrm{m} ; p=1.00$ ), compared with the homozygous GluR $\delta 2^{-1-} / \operatorname{Tg}_{\mathrm{wt}}$ (Fig. $2 A, B$ ). Indeed, at extrasynaptic cell surfaces and CF-Purkinje cell synapses, immunogold particles were rarely observed in either homozygous GluR $\delta 2^{-/-} / T g_{\mathrm{wt}}(0.5 \pm 0.3$ particles/ $\mu \mathrm{m}$ at extrasynaptic cell surfaces, $0.9 \pm 0.2$ particles $/ \mu \mathrm{m}$ at CF-Purkinje cell synapses) or homozygous GluR $\delta 2^{-/-} / \mathrm{Tg}_{\Delta \mathrm{CT} 7}$ mice $(0.3 \pm 0.2$ particles/ $\mu \mathrm{m}$ at extrasynaptic cell surfaces; $0.5 \pm$ 0.1 particles/ $\mu \mathrm{m}$ at CF-Purkinje cell synapses; both $p<0.001$ vs
PF-Purkinje cell synapses) (supplemental Fig. S2, available at www.jneurosci.org as supplemental material), indicating that transgene proteins were selectively expressed at PF-Purkinje cell synapses. Furthermore, the immunoblot analysis revealed that the homozygous $G l u R \delta 2^{-/-} / \mathrm{Tg}_{\mathrm{wt}}$ and homozygous $G l u R \delta 2^{-/-}$, $T g_{\Delta \text { CT7 }}$ lines expressed comparable levels of GluR $\delta 2$ transgene proteins in the PSD fraction of cerebellar lysates $(n=3$; $t$ test, $p=$ 0.813 ) (Fig. 2C). Therefore, GluR $\delta 2$ lacking its $\mathrm{C}$ terminus could be normally localized at the PSD of PF-Purkinje cell synapses, although the efficiency of this localization was approximately half of that of wild-type GluR $\delta 2$, indicating a facilitative but nonessential role of the $\mathrm{C}$ terminus in the synaptic localization of GluR $\delta 2$.

To investigate other functions mediated by the $\mathrm{C}$ terminus of GluR $\delta 2$, we compared the phenotypes of homozygous $G l u R \delta 2^{-1-}$ / $T g_{\mathrm{wt}}$ and homozygous GluR $\delta 2^{-/-} / \mathrm{Tg}_{\Delta \mathrm{CT} 7}$ mice in the following analyses, because these lines expressed similar amounts of transgene products at their PF-Purkinje cell synapses.

\section{Impaired cerebellar LTD in GluR $\delta 2^{-/-} / \mathrm{Tg}_{\Delta \mathrm{CT} 7}$ mice}

First, we examined whether abrogated LTD in GluR $\delta 2$-null Purkinje cells was rescued by $T g_{\Delta \mathrm{CT} 7}$. No difference in PF-EPSC kinetics was observed between GluR $\delta 2^{-/-} / \mathrm{Tg}_{\mathrm{wt}}$ (10-90\% rise time, $3.3 \pm 0.2 \mathrm{~ms}, n=20$; decay time constant, $14.7 \pm 0.7 \mathrm{~ms}$; $n=20)$ and GluR $\delta 2^{-/-} / \mathrm{Tg}_{\Delta \mathrm{CT} 7}$ mice $(10-90 \%$ rise time, $3.1 \pm$ $0.2 \mathrm{~ms}, n=12$, $t$ test, $p=0.290$; decay time constant, $16 \pm 0.9 \mathrm{~ms}$, $n=12$; $t$ test, $p=0.250$ ), indicating that the basal properties of AMPA receptors were unaffected by the deletion of the PDZbinding motif of GluR $\delta 2$. As reported previously (Hirai et al., 2005), the conjunctive stimulation of PFs and the depolarization of Purkinje cells induced no LTD in GluR $\delta 2^{-/-}$Purkinje cells (Fig. $3 A, D)(100 \pm 3 \%$ at $t=30 \mathrm{~min} ; n=6$ from four mice), whereas it induced robust LTD in GluR $\delta 2^{-/-} / \mathrm{Tg}_{\mathrm{wt}}$ Purkinje cells (Fig. $3 B, D)(69 \pm 6 \%$ at $t=30 \mathrm{~min}, n=6$ from four mice; one-way ANOVA followed by Bonferroni's test, $F_{(2,19)}=18.33$, $p<0.001$ vs $G l u R \delta 2^{-/-}$mice). In contrast, LTD was not fully restored in GluR $\delta 2^{-/-} / \mathrm{Tg}_{\Delta \mathrm{CT} 7}$ Purkinje cells (Fig. $\left.3 C, D\right)(87 \pm$

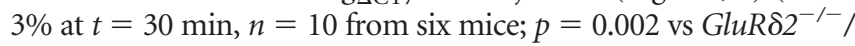
$T g_{\mathrm{wt}}$ mice, and $p=0.062$ vs GluR $\delta 2^{-/-}$mice). These results indicate that the $\mathrm{C}$ terminus of GluR $\delta 2$ mediates intracellular signals that are crucial for LTD induction, a finding consistent with our previous study using the virus-mediated expression of $\mathrm{Tg}_{\Delta \mathrm{CT}}$ (Kohda et al., 2007). Interestingly, in both studies, the expression of $T g_{\Delta \mathrm{CT} 7}$ produced a slight but significant reduction in the EPSC amplitude after conjunctive stimulation (Fig. 3D). Thus, there might be a minor component of cerebellar LTD that is induced independently of the PDZ protein-based signaling by GluR $\delta 2$.

\section{Restoration of PF release probability in GluR $\delta 2^{-/-} / T g_{\Delta \mathrm{CT} 7}$ mice}

In the previous study, although the Sindbis virus-mediated transient expression of $T g_{\mathrm{wt}}$ restored LTD induction, it failed to rescue the other phenotypes of GluR $\delta 2^{-1-}$ mice (Kohda et al., 2007). One of these phenotypes is an impairment in presynaptic function observed at PF-Purkinje cell synapses (Kashiwabuchi et al., 1995); GluR $\delta 2^{-/-}$mice exhibit increased PPF of PF-EPSCs, reflecting a lower presynaptic release probability (Zucker and Regehr, 2002). Indeed, the ratio of PPF at interpulse intervals $<350 \mathrm{~ms}$ was significantly elevated in GluR $\delta 2^{-/-}$Purkinje cells (Fig. $4 B, E)(2.38 \pm 0.07$ at $50 \mathrm{~ms}$ ISI; $n=15)$ than that in GluR $\delta 2^{+/+}$Purkinje cells (Fig. $\left.4 A, E\right)(1.64 \pm 0.04$ at $50 \mathrm{~ms}$ ISI; $n=20$; one-way ANOVA followed by Bonferroni's test, $F_{(3,75)}=$ 
29.38, $p<0.001)$. In contrast, Purkinje cells in GluR $\delta 2^{-/-} / \mathrm{Tg}_{\mathrm{wt}}$ mice (Fig. $4 C$ ) as well as in GluR $\delta 2^{-/-} / T g_{\Delta \mathrm{CT} 7}$ mice (Fig. $4 D)$ displayed PPF ratios that were significantly smaller (Fig. $4 E)(1.73 \pm 0.04$ at 50 ms ISI, $n=20$ and $1.80 \pm 0.07$ at $50 \mathrm{~ms}$ ISI; $n=24$, respectively) than that of GluR $\delta 2^{-1-}$ mice $(p<0.001$ for both transgenic mice) and comparable with that of GluR $\delta 2^{+/+}$mice (Fig. $\left.4 E\right)(p=1.000 \mathrm{vs}$ GluR $\delta 2^{-/-} / T g_{\text {wt }}$ mice, and $p=0.235$ vs GluR $\delta 2^{-1-} / T g_{\Delta \mathrm{CT} 7}$ mice). Therefore, the reduced release probability of PFs in GluR $\delta 2^{-1-}$ mice was completely restored by the expression of $T g_{\Delta \mathrm{CT} 7}$ as well as by the expression of $T g_{\text {wt }}$. Because GluR $\delta 2$ is expressed exclusively at postsynaptic sites, these results indicate that GluR $\delta 2$ is involved in a retrograde signaling pathway that modifies the presynaptic release probability; however, its $\mathrm{C}$ terminus is not required for this function. In addition, successful recovery of an impaired presynaptic function in GluR $\delta 2^{-/-}$mice by using the transgenic mice-based approach, but not by the virus-mediated approach, indicates that these phenotypes may require a longer time period of expression, which cannot be achieved by the Sindbis virus because of its cytotoxicity (Kohda et al., 2007).

\section{A GluR $\delta 2^{-1-}$}

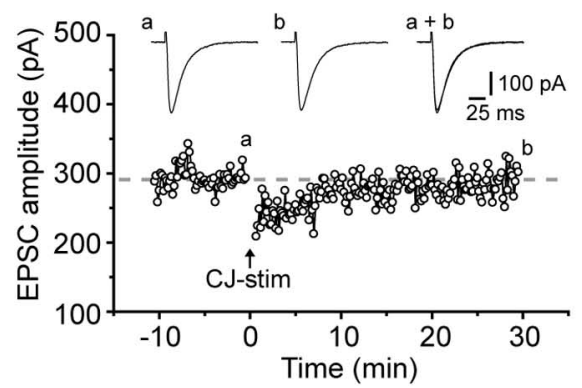

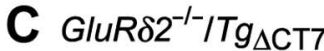

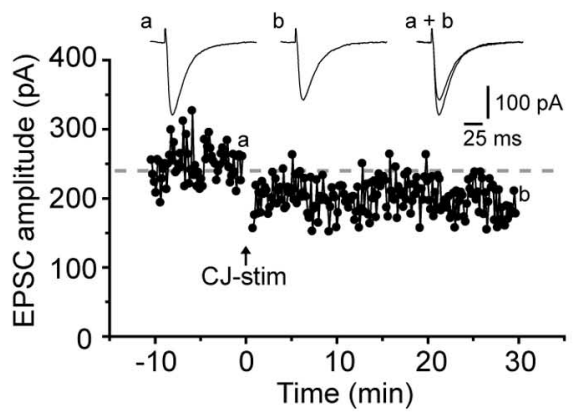

B GluR $\delta 2^{-1-} / T g_{\mathrm{wt}}$

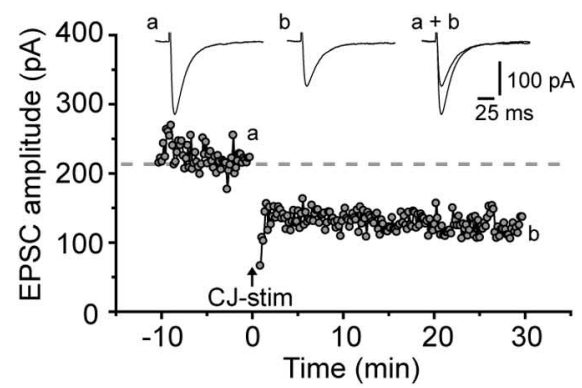

D

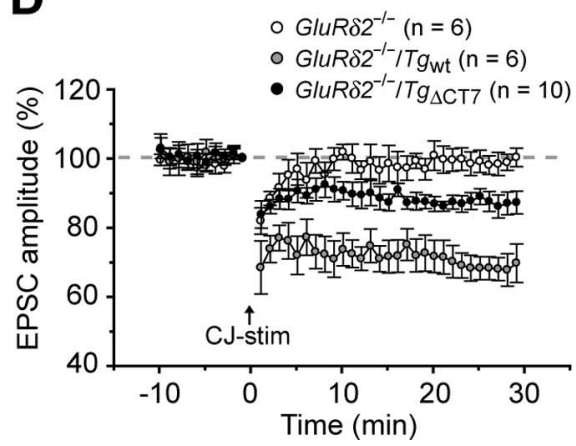

Figure 3. LTD at PF-Purkinje cell synapses is severely reduced in $G / u R \delta 2^{-/-} / T g_{\Delta C 77}$ mice. $A-C$, Representative LTD data

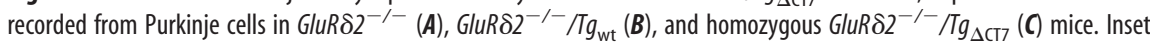
traces show the PF-EPSCs just before (a) or 30 min after (b) the conjunctive stimulation (CJ-stim, arrow) and their superimposition $(a+b)$. D, Summary of the LTD sessions in each mouse. The averaged amplitudes of the PF-EPSC over 1 min were normalized to the baseline value, which was the average of the 1 min responses (six traces) that occurred just before CJ-stim.

\section{Restoration of PF-Purkinje cell synaptic integrity in}

GluR $\delta 2^{-/-} / \mathrm{Tg}_{\Delta \mathrm{CT} 7}$ mice

GluR $\delta 2$ plays crucial roles in the formation and maintenance of PF-Purkinje cell synapses (Yuzaki, 2004); the number of PFPurkinje cell synapses was markedly reduced in GluR $\delta 2^{-/-}$cerebella, and many spines remain uninnervated without presynaptic contact (Kurihara et al., 1997; Lalouette et al., 2001). Interestingly, serial EM analysis revealed that almost all the spines

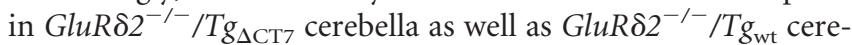
bella were in contacted with PF terminals (Fig. 5C,D) (98.4 $1.1 \%$ in GluR $\delta 2^{-/-} / \mathrm{Tg}_{\Delta \mathrm{CT} 7}$ mice, and (Fig. $\left.5 B, D\right)(99.7 \pm 0.3 \%$ in GluR $\delta 2^{-/-} / \mathrm{Tg}_{\mathrm{wt}}$ mice; total of 300 spines counted in three mice; $t$ test with Bonferroni's correction, $p=0.536$ ), whereas only $59.9 \pm 2.2 \%$ spines were in contacted with PFs in GluR $\delta 2^{-/-}$ cerebella (Fig. $5 A, D$ ) (total of 300 spines counted in three mice; $t$ test with Bonferroni's correction, $p<0.01$ ). In addition to the loss of PF synapses, the remaining PF-Purkinje cell synapses in GluR $\delta 2^{-1-}$ mice exhibit another unique phenotype: the length of the PSD does not match that of the opposing presynaptic active zone (Kurihara et al., 1997; Lalouette et al., 2001). Serial EM analysis revealed that the occurrence of mismatching between the PSD and the active zone at PF synapses was also significantly less frequent in GluR $\delta 2^{-/-} / \mathrm{Tg}_{\Delta \mathrm{CT} 7}$ cerebella $(7 \pm 5 \%)$ than in GluR $\delta 2^{-1-}$ cerebella ( $29 \pm 3 \% ; 300$ spines counted in three representative mice from each line; $t$ test with Bonferroni's correction, $p=0.019)$. However, it was still more frequent in GluR $\delta 2^{-\prime}$ $-/ T g_{\Delta \mathrm{CT} 7}$ cerebella than in $G l u R \delta 2^{-/-} / \mathrm{Tg}_{\mathrm{wt}}$ cerebella $(0.5 \pm$ $0.4 \%)$, although the difference was not statistically significant $(t$ test with Bonferroni's correction, $p=0.454)$. These results indicate that GluR $\delta 2$ lacking the $\mathrm{C}$ terminus could regulate PF-Purkinje cell synaptic integrity almost completely, although we can- not rule out the possibility of a minor contribution from a $\mathrm{C}$ terminus-based signaling pathway.

Innervation of GluR $\delta 2^{-/-} / \operatorname{Tg}_{\Delta \mathrm{CT} 7}$ Purkinje cells by single CFs Immature Purkinje cells are innervated by several CFs originating from the inferior olives of the medulla. The redundant CFs are gradually eliminated during development, and most Purkinje cells become innervated by single CFs by the end of the third postnatal week in mice. In contrast, many GluR $\delta 2^{-/-}$Purkinje cells remain innervated by multiple CFs even in adulthood, indicating that GluR $\delta 2$ plays a role in the developmental pruning of redundant CF inputs (Kashiwabuchi et al., 1995; Hashimoto et al., 2001). Because a single CF has a single threshold for excitation, increasing the stimulus intensity normally elicits CF-EPSCs in an all-or-none manner. Although single EPSCs were elicited in only $\sim 45 \%$ of the Purkinje cells from postnatal day 24 (P24) to P38 GluR $\delta 2^{-1-}$ mice (Fig. $6 A, B$ ), $>80 \%$ of the Purkinje cells from GluR $\delta 2^{-/-} / T g_{\Delta \mathrm{CT} 7}$ and GluR $\delta 2^{-/-} / T g_{\mathrm{wt}}$ mice attained a one-to-one relationship with CFs (Fig. $6 A, B$ ); this percentage was comparable with that of GluR $\delta 2^{+/+}$mice (Kashiwabuchi et al., 1995; Hashimoto et al., 2001). Some CF-EPSCs in GluR $\delta 2^{-/-}$ Purkinje cells are reportedly associated with a markedly slower rise time; this may be attributed to the abnormal CF innervation of the distal dendrites of GluR $\delta 2^{-/-}$Purkinje cells (Ichikawa et al., 2002; Miyazaki et al., 2004). However, CF-EPSCs in GluR $\delta 2^{-/-} / \mathrm{Tg}_{\Delta \mathrm{CT} 7}$ as well as GluR $\delta 2^{-/-} / \mathrm{Tg}_{\mathrm{wt}}$ cells had a rapid rise time similar to that in wild-type cells $(0.5 \pm 0.1 \mathrm{~ms}, n=14$ in GluR $\left.\delta 2^{-/-} / \mathrm{Tg}_{\Delta \mathrm{CT} 7} ; 0.5 \pm 0.1 \mathrm{~ms}, n=19 \mathrm{in} G l u R \delta 2^{-/-} / \mathrm{Tg}_{\mathrm{wt}}\right)$ (Fig. $6 \mathrm{~A}$ ). These results indicate that although the virus-mediated transient expression of $T g_{\Delta \mathrm{CT} 7}$ did not work (Kohda et al., 2007), the transgenic mice-based expression of $\mathrm{Tg}_{\Delta \mathrm{CT} 7}$ restored the normal process of CF synapse elimination in GluR $\delta 2^{-/-}$mice. 


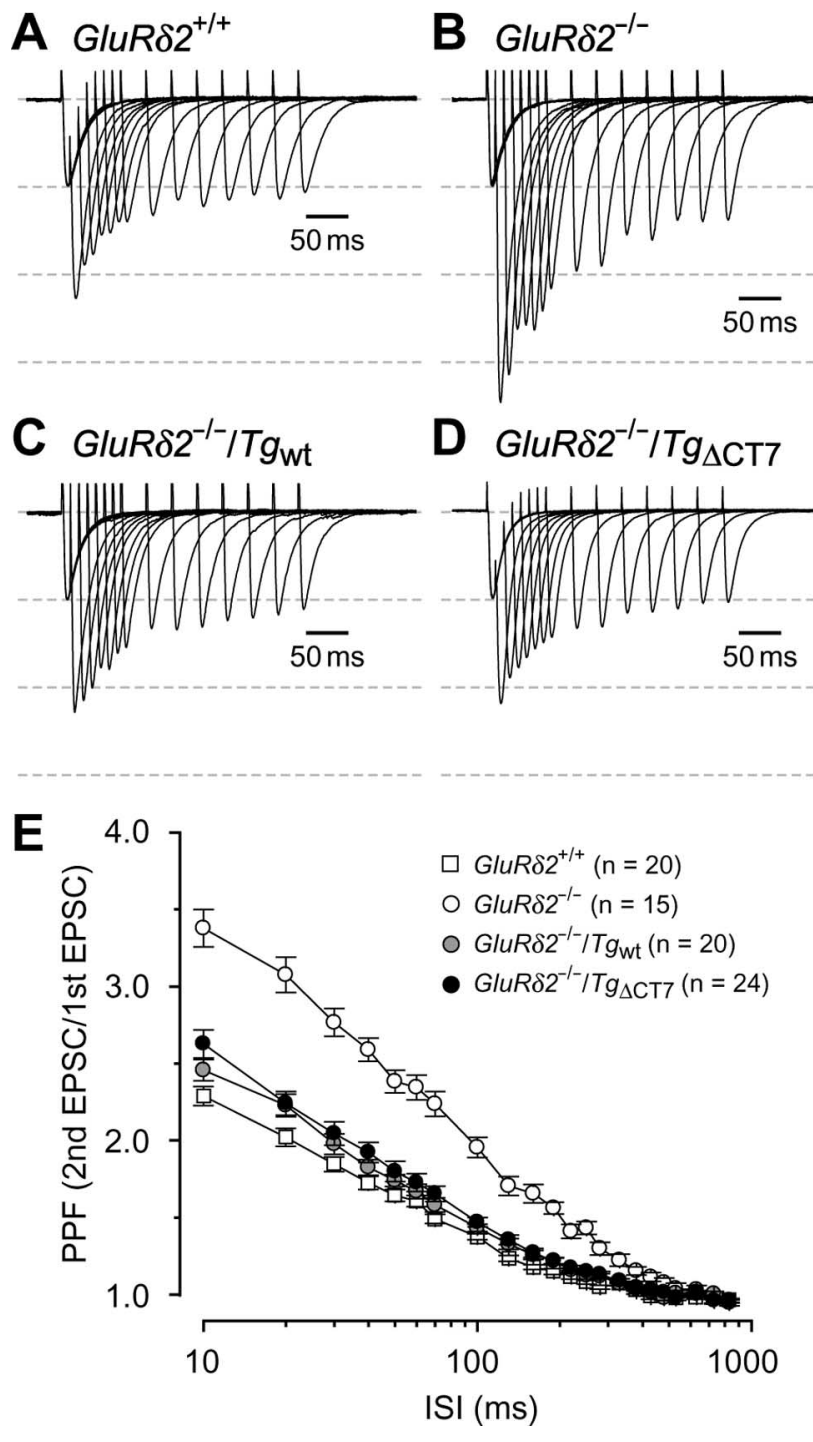

Figure 4. Rescue from the enhanced PPF of PF-EPSCs in GluR $\delta 2^{-/-}$mice by $T g_{\Delta C T 7}$ expression. $\boldsymbol{A}-\boldsymbol{D}$, Representative PF-EPSCs recorded from Purkinje cells clamped at $-70 \mathrm{mV}$ in GluR $\delta 2^{+/+}(\boldsymbol{A})$, GluR $\delta 2^{-/-}(\boldsymbol{B})$, GluR $\delta 2^{-/-} / \mathrm{Tg}_{\mathrm{wt}}(\boldsymbol{C})$, and homozygous GluR $\delta 2^{-/-} / T g_{\Delta \mathrm{CT} 7}$ (D) mice. All traces were normalized with the first PF-EPSC amplitude. The widths between the dashed lines correspond to the amplitude of the first PF-EPSC. E, Summarized plots of the PPF values of the PF-EPSCS, which were defined as the amplitude of the second EPSC divided by that of the first EPSC, in various ISI ( $10-830 \mathrm{~ms})$.

\section{Impaired cerebellar motor learning in $G l u R \delta 2^{-/-} / T g_{\Delta C T 7}$ mice}

Finally, we examined whether the motor discoordination and impaired motor learning observed in GluR $\delta 2^{-1-}$ mice in vivo (Kashiwabuchi et al., 1995; Kishimoto et al., 2001) could be rescued by the expression of $T g_{\triangle \mathrm{CT} 7}$. Unlike GluR $\delta 2^{-1-}$ mice, GluR $\delta 2^{-1-} / T g_{\Delta \mathrm{CT} 7}$ mice as well as GluR $\delta 2^{-/-} / \mathrm{Tg}_{\mathrm{wt}}$ mice exhibited no ataxia and could walk along a straight line with regular steps (Fig. 7A) (supplemental movie S1, available at www. jneurosci.org as supplemental material). Similarly, GluR $\delta 2^{-1-}$, $T g_{\Delta \mathrm{CT} 7}$ mice performed as well as $G l u R \delta 2^{-/-} / T g_{\mathrm{wt}}$ and GluR $\delta 2^{+/+}$mice did on the rotor-rod task at $10 \mathrm{rpm}$ (Fig. $7 B$ ) (one-way ANOVA followed by Bonferroni's test, $F_{(3,51)}=33.91$, $p>0.05$ for both mice). However, when the test was performed

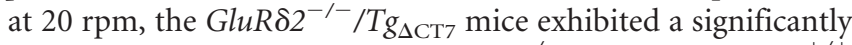
poorer performance than the GluR $\delta 2^{-/-} / T g_{\mathrm{wt}}$ and GluR $\delta 2^{+/+}$ mice (Fig. 7B) (one-way ANOVA followed by Bonferroni's test,
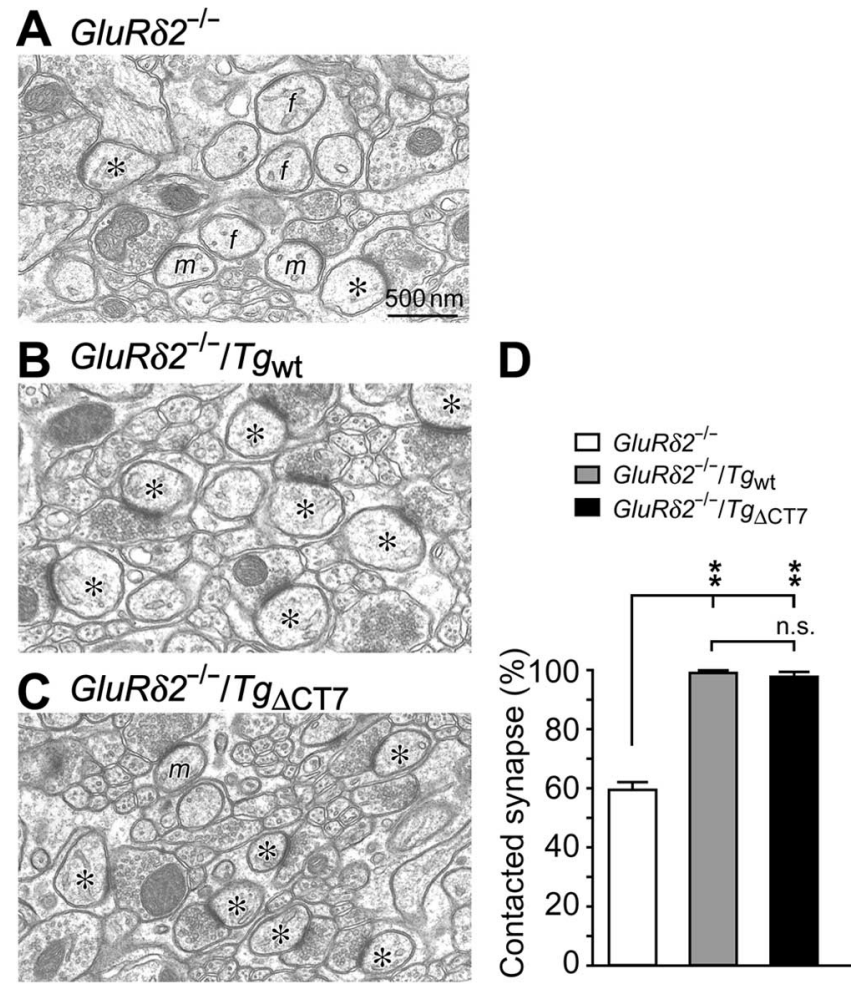

Figure 5. Rescue of impaired PF-Purkinje cell synaptic integrity in GluR $\delta 2^{-/-}$mice by $T g_{\Delta C T 7}$ expression. $\boldsymbol{A}-\boldsymbol{C}$, Representative EM images showing PF-Purkinje cell synapses in GluR $\delta 2^{-\prime-}(\boldsymbol{A})$, GluR $\delta 2^{-/-} / T g_{\mathrm{wt}}(\boldsymbol{B})$, and homozygous GluR $\delta 2^{-/-} / T g_{\Delta \mathrm{CT}}(\boldsymbol{C})$ cerebella. The asterisks indicate Purkinje cell spines in contact with PF terminals, and $\mathrm{f}$ and $\mathrm{m}$ indicate free/ naked spine and mismatched synapses, respectively. $\boldsymbol{D}$, Quantitative data showing the percentage of contacted synapses of the 300 total Purkinje cell spines counted in three mice. ${ }^{* *} p<$ 0.01 . n.s., No significance.

$F_{(3,58)}=85.09, p<0.001$ for both mice). Furthermore, the delayed eyeblink conditioning test, which reflects cerebellumdependent classical associative learning (Ito, 1989; Thompson and Krupa, 1994), revealed that unlike $T g_{\text {wt, }} T g_{\Delta \mathrm{CT} 7}$ could not rescue impaired motor learning in GluR $\delta 2^{-1}$ mice (Fig. $7 C$ ) (one-way ANOVA followed by Bonferroni's test, $F_{(3,30)}=4.60$, $p=0.038$ vs $G l u R \delta 2^{+/+} ; p=0.011$ vs $G l u R \delta 2^{-/-} / T g_{\mathrm{wt}}$ mice). These results suggest that because GluR $\delta 2$ lacking the C-terminal PDZ-binding motif could restore the motor coordination required for gait and motor coordination during the less demanding rotor-rod task, it may convey indispensable signals necessary for motor coordination during complex motor tasks and motor learning in vivo.

\section{Discussion}

In the present study, we demonstrated that although a mutant GluRS2 transgene lacking the C-terminal PDZ-binding motif successfully rescued several abnormalities of the $G l u R \delta 2^{-1-}$ cerebellum, such as enhanced PPF at PF-Purkinje cell synapses (Fig. 4), the appearance of uninnervated spines (Fig. 5), and the sustained innervation of Purkinje cells by multiple CFs (Fig. 6), it could not restore abrogated LTD at PF-Purkinje cell synapses (Fig. 3). Furthermore, although the gross motor discoordination of GluR $\delta 2^{-1-}$ mice was restored (Fig. 7) (supplemental movie S1, available at www.jneurosci.org as supplemental material), the cerebellar motor learning underlying eyeblink conditioning remained impaired even after the expression of $T g_{\Delta \mathrm{CT} 7}$ (Fig. 7). These findings indicate, for the first time, that signaling via the 


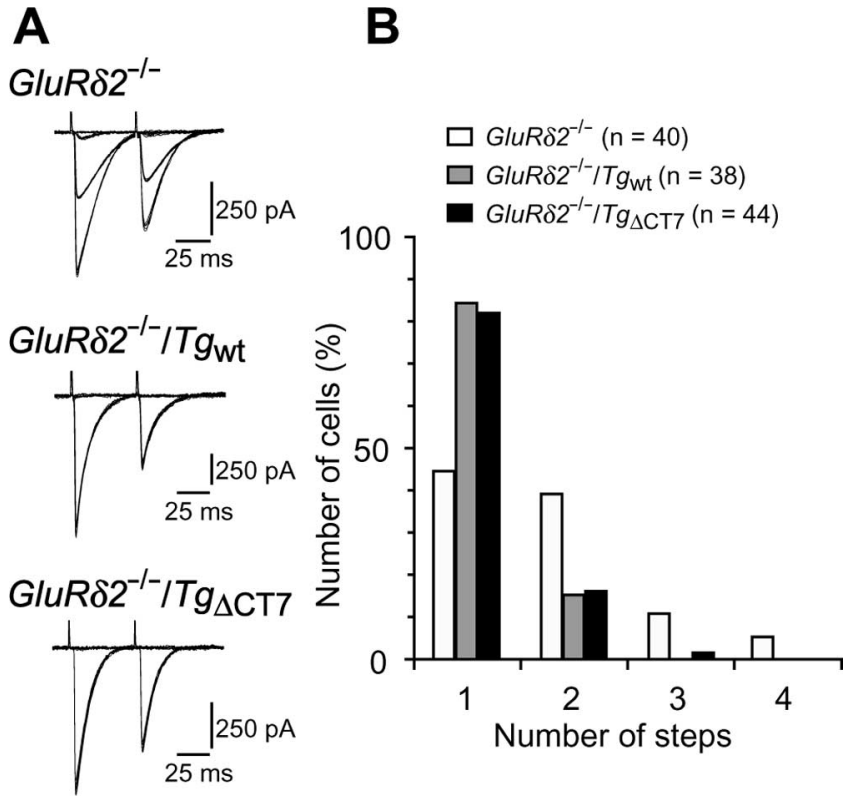

Figure 6. Rescue of multiple (F innervation pattern in a single Purkinje cell from a GluRS2 $2^{-/-}$mouse by $T g_{\Delta \text { CT7 }}$ expression. A, Representative CF-EPSCs (ISI, $50 \mathrm{~ms}$ ) recorded

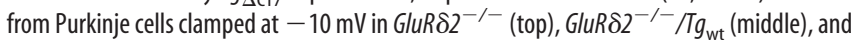

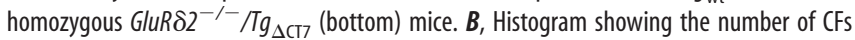
innervating single Purkinje cells in each mouse. The number of CF-EPSCs induced by different stimuli thresholds $(0-200 \mu \mathrm{A})$ was counted.

C-terminal end of GluR $\delta 2$ was dispensable for morphological integrity at PF and CF synapses, whereas signaling was absolutely required for the induction of LTD and motor learning.

\section{LTD as a major mechanism underlying motor learning in the cerebellum}

Although recent studies using genetically modified mice primarily support the hypothesis that LTD of PF-Purkinje cell synapses underlies certain forms of associative motor learning, some developmental abnormalities that are often observed in these mice, such as the sustained innervation of Purkinje cells by multiple CFs and the reduction in PF synapses, have precluded an unequivocal interpretation. For example, mice lacking GluR $\delta 2$ (Kashiwabuchi et al., 1995), metabotropic glutamate receptor 1 (Aiba et al., 1994; Conquet et al., 1994), phospholipase C $\beta 4$ (Miyata et al., 2001), or G $\alpha$ q (Hartmann et al., 2004) all show impaired LTD together with abnormal CF innervation patterns. Furthermore, because most signaling molecules involved in LTD are not specific to PF-Purkinje cell synapses, the genetic modification of these molecules may also affect other synapses. For example, although motor learning was impaired in L7-PKCI transgenic mice (De Zeeuw et al., 1998), in which protein kinase $\mathrm{C}$ (PKC) activities were specifically inhibited in Purkinje cells, all isoforms of PKCs may have been affected in all synapses, including $\mathrm{PF}-, \mathrm{CF}-$, and interneuron-Purkinje cell synapses. Importantly, GluR $\delta 2^{-/-} / \mathrm{Tg}_{\Delta \mathrm{CT} 7}$ mice are unique in that they showed impairment in LTD and motor learning in the absence of morphological abnormalities at CF or PF synapses and that the transgene was specifically expressed at PF-Purkinje cell synapses (Figs. $1 C, 2$ ) (supplemental Fig. S2, available at www.jneurosci.org as supplemental material). To the best of our knowledge, no neuronal circuits have ever been related to a behavioral defect at this level of synaptic specificity. Therefore, the data strongly support the notion that cerebellar LTD at PF synapses, although not es- sential for gross motor coordination, is a major mechanisms underlying motor learning during eyeblink conditioning.

\section{Transgenic mice-based rescue approach}

In the previous study, we showed that the virus-mediated expression of $T g_{\mathrm{wt}}$, but not $T g_{\Delta \mathrm{CT} 7}$, could successfully rescue impaired LTD induction in GluR $\delta 2^{-/-}$Purkinje cells in slice preparations (Kohda et al., 2007). In contrast, LTD was normally induced in cultured GluR $\delta 2^{-/-}$Purkinje cells transfected with a mutant GluR $\delta 2$ that lacked the PDZ-ligand domain (Yawata et al., 2006). In that study, glutamate was iontophoretically applied to Purkinje cells to induce LTD and to monitor the AMPA currents; thus, the observed phenomenon may have included changes at extrasynaptic regions. Moreover, molecular mechanisms underlying LTD in cultured Purkinje cells may not be exactly the same as those observed in slice preparations. The present data obtained from transgenic mice confirmed our previous result that the $\mathrm{C}$ terminus of GluR $\delta 2$ was indispensable for the induction of LTD. Furthermore, other functions of GluR $\delta 2$ in Purkinje cells such as the regulation of PF synaptic integrity, PF release probability, and motor learning in vivo could only be examined using the transgenic mice-based rescue approach, which enables stable and long-term expression of transgenes in vivo.

Another advantage of the transgenic mice-based approach is that we could obtain several lines of mice expressing various levels of transgene protein. In this study, by comparing hemizygous GluR $\delta 2^{-1-} / \mathrm{Tg}_{\Delta \mathrm{CT} 7}$ mice with homozygous GluR $\delta 2^{-/-} / \mathrm{Tg}_{\mathrm{wt}}$ mice, which had similar total transgene protein expression levels (Fig. $1 D$ ), we were able to demonstrate a facilitatory role of the $\mathrm{C}$ terminus in the synaptic localization of GluR $\delta 2$. In contrast, the expression level of the transgenes is difficult to control precisely using a virus-based or transfection-based approach. For example, we previously reported that virally expressed $\mathrm{Tg}_{\Delta \mathrm{CT} 7}$ and $\mathrm{Tg}_{\mathrm{wt}}$ proteins were similarly localized at the dendritic spines of Purkinje cells (Kohda et al., 2007). We suspect that the overexpression of transgenes by viral promoters may have masked the slight facilitatory role of the $\mathrm{C}$ terminus.

The structure-function relationship of a gene product can also be examined using a knock-in approach, in which an endogenous gene is replaced with a mutant gene by homologous recombination. This approach has an advantage in that, unlike transgenic mice-based method, the total expression levels of the mutant gene are similar to those of the endogenous gene. However, if a mutation modifies the protein expression levels at synapses, its effect on other synaptic functions should be carefully interpreted, because the total expression levels of mutant genes are fixed in knock-in mouse. In contrast, by comparing homozygous GluR $\delta 2^{-/-} / \mathrm{Tg}_{\Delta \mathrm{CT} 7}$ mice with homozygous GluR $\delta 2^{-/-}$, $T g_{\text {wt }}$ mice, which expressed similar amounts of protein at their synapses, we could elucidate the direct role of the $\mathrm{C}$ terminus of GluR $\delta 2$ on LTD and motor learning, separately from its role on synaptic localization.

\section{Functions achieved by the C terminus of GluR $\delta 2$}

Our present study indicated that functions of GluR $\delta 2$ could be classified into at least two categories: those that highly depend on the C-terminal PDZ-binding motif, and those that have a weaker relationship. Although the induction of LTD at PF synapses critically required intracellular signals mediated by the $\mathrm{C}$ terminus of GluR $\delta 2$, the morphological integrity at PF and CF synapses and presynaptic PF function did not absolutely require such signals. The failure of $T g_{\Delta \mathrm{CT} 7}$ to rescue LTD is unlikely to reflect a difference in the sensitivity of this assay, because abrogated LTD was 
A

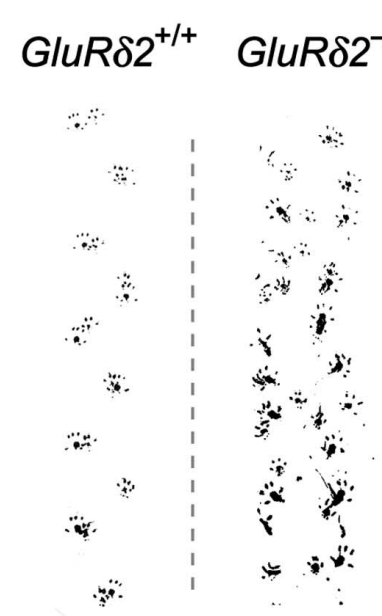

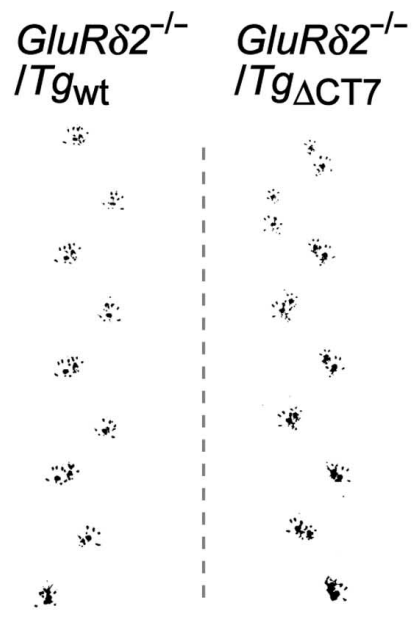

B

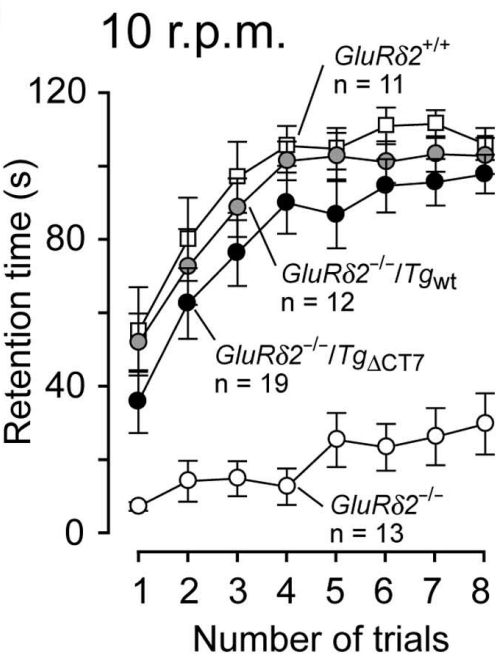

20 r.p.m.

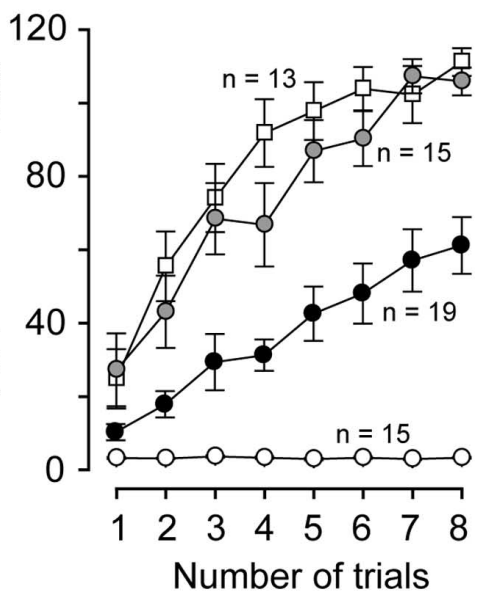

C

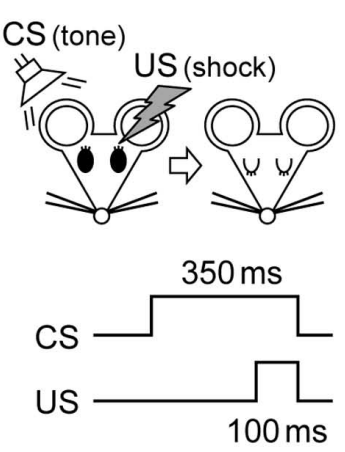

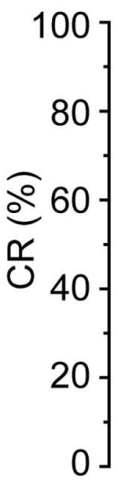
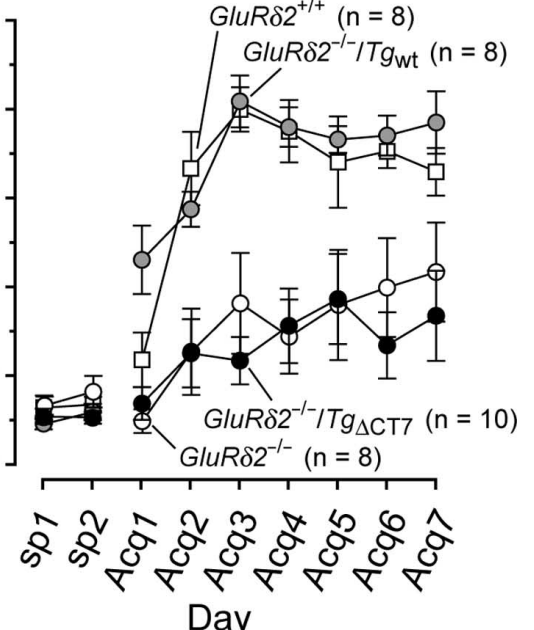

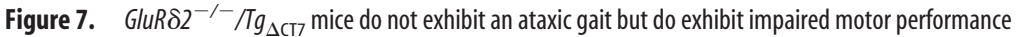
and cerebellar motor learning. $\boldsymbol{A}$, Representative walking footprint patterns in each mouse. $\boldsymbol{B}$, Results of rotor-rod

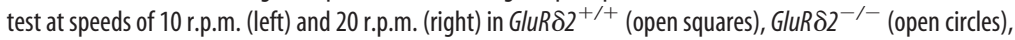
GluR $\delta 2^{-/-} / T g_{\text {wt }}$ (gray circles), and homozygous GluR $\delta 2^{-1-} / T g_{\Delta C T 7}$ (filled circles) mice. The mice were allowed a maximum retention time of 120 s per trial. $\boldsymbol{C}$, Results of a delay eyeblink conditioning test. The left diagram shows the temporal relationship between CS (tone, $350 \mathrm{~ms}$ ) and US (electric shock, $100 \mathrm{~ms}$ ). In the acquisition (Acq) phase from days 1 to 7 (Acq1 to Acq7), the daily sessions consisted of 10 blocks of trials in which each block consisted of nine CS-US paired trials and one CS-only trial. The $y$-axis shows the percentage of CR against CS; the CR values at days before training (sp1 and sp2) indicate the spontaneous eyeblink responses.

restored by even half the amount of GluR $\delta 2$ proteins at the synapses in the hemizygous $G l u R \delta 2^{-/-} / \mathrm{Tg}_{\mathrm{wt}}$ mice (Yuzaki, 2005). Thus, these two classes of functions likely reflect distinct mechanisms by which GluR $\delta 2$ operates in Purkinje cells.

Although GluR $\delta 2$ signaling mechanisms remain primarily unknown even after its cloning $>14$ years ago, the results of this study provide the first clue as to where to look for keys to GluR $\delta 2$ signaling: molecules that bind to the C-terminal 7 amino acids of GluR $\delta 2$ play a crucial role in LTD induction and motor learning. For example, delphilin is reported to bind Src tyrosine kinase via the FH1 domain (Miyagi et al., 2002), and PTPMEG contains a protein tyrosine phosphatase domain (Hironaka et al., 2000). Because cerebellar LTD depends on the tyrosine phosphorylation status in Purkinje cells (Boxall et al., 1996), the C terminus of GluR $\delta 2$ may regulate LTD induction through an interaction with delphilin and PTPMEG.

In contrast, the morphological integrity at PF synapses may not require the $\mathrm{C}$ terminus. Similarly, reduced PF presynaptic release probability in GluR $\delta 2^{-/-}$mice was completely restored by the expression of $T g_{\triangle \mathrm{CT}}$ (Fig. 4). Recently, many synaptic adhesion molecules have been shown not only to participate in the formation of synapses but also to regulate presynaptic functions (Dalva et al., 2007). For example, presynaptic release probabilities were regulated by postsynaptic adhesion molecules such as EphB (Contractor et al., 2002), N-cadherin (Jungling et al., 2006), and neuroligin (Futai et al., 2007) by interacting with their presynaptic counterparts. Although many adhesion molecules are anchored at postsynaptic sites by multiple intracellular proteinprotein interactions involving C-terminal domains of AMPA and NMDA receptors (Contractor et al., 2002; Futai et al., 2007; Silverman et al., 2007), the $\mathrm{N}$-terminal extracellular domain of AMPA receptors has been shown recently to bind to $\mathrm{N}$-cadherin (Nuriya and Huganir, 2006; Saglietti et al., 2007). Therefore, we speculate that the N-terminal domain of GluR $\delta 2$ may also bind directly or indirectly to some adhesion molecules located at the presynaptic sites, thereby regulating morphological synaptic integrity and presynaptic functions.

To what extent the second class of functions depends on the C terminus of GluR $\delta 2$, however, remains unclear. For example, although not statistically significant, the occurrence of mismatching between the PSD and the active zone at PF synapses was higher in GluR $\delta 2^{-/-} / \operatorname{Tg}_{\Delta \mathrm{CT} 7}$ than in GluR $\delta 2^{-/-} / T g_{\mathrm{wt}}$ cerebella. In addition, although CF-EPSCs in GluR $\delta 2^{-1-} / \operatorname{Tg}_{\Delta \mathrm{CT} 7}$ Purkinje cells showed normal kinetics, the puncta that were immunopositive for vesicular glutamate transporter 2 , which is predominantly expressed at CF terminals, tended to reach the distal region of Purkinje cell dendrites (data not shown). Thus, although the uninnervated PF synapses (Fig. 5) and sustained innervation by multiple CFs (Fig. 6) were completely rescued in GluR $\delta 2^{-/-} / \mathrm{Tg}_{\triangle \mathrm{CT} 7}$ Purkinje cells, minor abnormalities that may require additional signaling via the $\mathrm{C}$ terminus of GluR $\delta 2$ remained. To address this issue 
more clearly, new rescue lines that express higher levels of $T g_{\Delta \mathrm{CT} 7}$ are necessary. Nevertheless, the C-terminal PDZ-binding motif is not crucial for most of the functions of GluR $\delta 2$ that are related to morphological synaptic integrity in the cerebellum.

\section{References}

Aiba A, Kano M, Chen C, Stanton ME, Fox GD, Herrup K, Zwingman TA, Tonegawa S (1994) Deficient cerebellar long-term depression and impaired motor learning in mGluR1 mutant mice. Cell 79:377-388.

Araki K, Meguro H, Kushiya E, Takayama C, Inoue Y, Mishina M (1993) Selective expression of the glutamate receptor channel $\delta 2$ subunit in cerebellar Purkinje cells. Biochem Biophys Res Commun 197:1267-1276.

Boxall AR, Lancaster B, Garthwaite J (1996) Tyrosine kinase is required for long-term depression in the cerebellum. Neuron 16:805-813.

Conquet F, Bashir ZI, Davies CH, Daniel H, Ferraguti F, Bordi F, Franz-Bacon K, Reggiani A, Matarese V, Conde F, Collingridge GL, Crepel F (1994) Motor deficit and impairment of synaptic plasticity in mice lacking mGluR1. Nature 372:237-243.

Contractor A, Rogers C, Maron C, Henkemeyer M, Swanson GT, Heinemann SF (2002) Trans-synaptic Eph receptor-ephrin signaling in hippocampal mossy fiber LTP. Science 296:1864-1869.

Dalva MB, McClelland AC, Kayser MS (2007) Cell adhesion molecules: signalling functions at the synapse. Nat Rev Neurosci 8:206-220.

De Zeeuw CI, Hansel C, Bian F, Koekkoek SK, van Alphen AM, Linden DJ, Oberdick J (1998) Expression of a protein kinase C inhibitor in Purkinje cells blocks cerebellar LTD and adaptation of the vestibulo-ocular reflex. Neuron 20:495-508.

Fukaya M, Kato A, Lovett C, Tonegawa S, Watanabe M (2003) Retention of NMDA receptor NR2 subunits in the lumen of endoplasmic reticulum in targeted NR1 knockout mice. Proc Natl Acad Sci USA 100:4855-4860.

Futai K, Kim MJ, Hashikawa T, Scheiffele P, Sheng M, Hayashi Y (2007) Retrograde modulation of presynaptic release probability through signaling mediated by PSD-95-neuroligin. Nat Neurosci 10:186-195.

Hartmann J, Blum R, Kovalchuk Y, Adelsberger H, Kuner R, Durand GM, Miyata M, Kano M, Offermanns S, Konnerth A (2004) Distinct roles of $\mathrm{G} \alpha(\mathrm{q})$ and $\mathrm{G} \alpha 11$ for Purkinje cell signaling and motor behavior. J Neurosci 24:5119-5130.

Hashimoto K, Ichikawa R, Takechi H, Inoue Y, Aiba A, Sakimura K, Mishina M, Hashikawa T, Konnerth A, Watanabe M, Kano M (2001) Roles of glutamate receptor $\delta 2$ subunit $(\mathrm{GluR} \delta 2)$ and metabotropic glutamate receptor subtype 1 (mGluR1) in climbing fiber synapse elimination during postnatal cerebellar development. J Neurosci 21:9701-9712.

Hirai H, Miyazaki T, Kakegawa W, Matsuda S, Mishina M, Watanabe M, Yuzaki M (2005) Rescue of abnormal phenotypes of the $\delta 2$ glutamate receptor-null mice by mutant $\delta 2$ transgenes. EMBO Rep 6:90-95.

Hironaka K, Umemori H, Tezuka T, Mishina M, Yamamoto T (2000) The protein-tyrosine phosphatase PTPMEG interacts with glutamate receptor $\delta 2$ and $\varepsilon$ subunits. J Biol Chem 275:16167-16173.

Ichikawa R, Miyazaki T, Kano M, Hashikawa T, Tatsumi H, Sakimura K, Mishina M, Inoue Y, Watanabe M (2002) Distal extension of climbing fiber territory and multiple innervation caused by aberrant wiring to adjacent spiny branchlets in cerebellar Purkinje cells lacking glutamate receptor $\delta 2$. J Neurosci 22:8487-8503.

Ito M (1989) Long-term depression. Annu Rev Neurosci 12:85-102.

Jungling K, Eulenburg V, Moore R, Kemler R, Lessmann V, Gottmann K (2006) N-cadherin transsynaptically regulates short-term plasticity at glutamatergic synapses in embryonic stem cell-derived neurons. J Neurosci 26:6968-6978.

Kakegawa W, Miyazaki T, Hirai H, Motohashi J, Mishina M, Watanabe M, Yuzaki M (2007) $\mathrm{Ca}^{2+}$ permeability of the channel pore is not essential for the $\delta 2$ glutamate receptor to regulate synaptic plasticity and motor coordination. J Physiol (Lond) 579:729-735.

Kashiwabuchi N, Ikeda K, Araki K, Hirano T, Shibuki K, Takayama C, Inoue Y, Kutsuwada T, Yagi T, Kang Y, Aizawa S, Mishina M (1995) Impairment of motor coordination, Purkinje cell synapse formation, and cerebellar long-term depression in GluR $\delta 2$ mutant mice. Cell 81:245-252.
Kishimoto Y, Kawahara S, Suzuki M, Mori H, Mishina M, Kirino Y (2001) Classical eyeblink conditioning in glutamate receptor subunit $\delta 2$ mutant mice is impaired in the delay paradigm but not in the trace paradigm. Eur J Neurosci 13:1249-1253.

Kohda K, Kakegawa W, Matsuda S, Nakagami R, Kakiya N, Yuzaki M (2007) The extreme C-terminus of GluR $\delta 2$ is essential for induction of long-term depression in cerebellar slices. Eur J Neurosci 25:1357-1362.

Kurihara H, Hashimoto K, Kano M, Takayama C, Sakimura K, Mishina M, Inoue $Y$, Watanabe M (1997) Impaired parallel fiber-Purkinje cell synapse stabilization during cerebellar development of mutant mice lacking the glutamate receptor $\delta 2$ subunit. J Neurosci 17:9613-9623.

Lalouette A, Lohof A, Sotelo C, Guenet J, Mariani J (2001) Neurobiological effects of a null mutation depend on genetic context: comparison between two hotfoot alleles of the delta-2 ionotropic glutamate receptor. Neuroscience 105:443-455.

Landsend AS, Amiry-Moghaddam M, Matsubara A, Bergersen L, Usami S, Wenthold RJ, Ottersen OP (1997) Differential localization of $\delta$ glutamate receptors in the rat cerebellum: coexpression with AMPA receptors in parallel fiber-spine synapses and absence from climbing fiber-spine synapses. J Neurosci 17:834-842.

Lomeli H, Sprengel R, Laurie DJ, Kohr G, Herb A, Seeburg PH, Wisden W (1993) The rat $\delta 1$ and $\delta 2$ subunits extend the excitatory amino acid receptor family. FEBS Lett 315:318-322.

Miyagi Y, Yamashita T, Fukaya M, Sonoda T, Okuno T, Yamada K, Watanabe M, Nagashima Y, Aoki I, Okuda K, Mishina M, Kawamoto S (2002) Delphilin: a novel PDZ and formin homology domain-containing protein that synaptically colocalizes and interacts with glutamate receptor $\delta 2$ subunit. J Neurosci 22:803-814.

Miyata M, Kim HT, Hashimoto K, Lee TK, Cho SY, Jiang H, Wu Y, Jun K, Wu D, Kano M, Shin HS (2001) Deficient long-term synaptic depression in the rostral cerebellum correlated with impaired motor learning in phospholipase C beta4 mutant mice. Eur J Neurosci 13:1945-1954.

Miyazaki T, Hashimoto K, Shin HS, Kano M, Watanabe M (2004) P/Q-type $\mathrm{Ca}^{2+}$ channel $\alpha 1$ A regulates synaptic competition on developing cerebellar Purkinje cells. J Neurosci 24:1734-1743.

Nuriya M, Huganir RL (2006) Regulation of AMPA receptor trafficking by N-cadherin. J Neurochem 97:652-661.

Saglietti L, Dequidt C, Kamieniarz K, Rousset MC, Valnegri P, Thoumine O, Beretta F, Fagni L, Choquet D, Sala C, Sheng M, Passafaro M (2007) Extracellular interactions between GluR2 and N-cadherin in spine regulation. Neuron 54:461-477.

Sheng M, Sala C (2001) PDZ domains and the organization of supramolecular complexes. Annu Rev Neurosci 24:1-29.

Silverman JB, Restituito S, Lu W, Lee-Edwards L, Khatri L, Ziff EB (2007) Synaptic anchorage of AMPA receptors by cadherins through neural plakophilin-related arm protein AMPA receptor-binding protein complexes. J Neurosci 27:8505-8516.

Takayama C, Nakagawa S, Watanabe M, Mishina M, Inoue Y (1995) Lightand electron-microscopic localization of the glutamate receptor channel $\delta 2$ subunit in the mouse Purkinje cell. Neurosci Lett 188:89-92.

Thompson RF, Krupa DJ (1994) Organization of memory traces in the mammalian brain. Annu Rev Neurosci 17:519-549.

Yawata S, Tsuchida H, Kengaku M, Hirano T (2006) Membrane-proximal region of glutamate receptor $\delta 2$ subunit is critical for long-term depression and interaction with protein interacting with $\mathrm{C}$ kinase 1 in a cerebellar Purkinje neuron. J Neurosci 26:3626-3633.

Yuzaki M (2004) The $\delta 2$ glutamate receptor: a key molecule controlling synaptic plasticity and structure in Purkinje cells. Cerebellum 3:89-93.

Yuzaki M (2005) Transgenic rescue for characterizing orphan receptors: a review of delta2 glutamate receptor. Transgenic Res 14:117-121.

Zhao HM, Wenthold RJ, Wang YX, Petralia RS (1997) $\delta$-Glutamate receptors are differentially distributed at parallel and climbing fiber synapses on Purkinje cells. J Neurochem 68:1041-1052.

Zucker RS, Regehr WG (2002) Short-term synaptic plasticity. Annu Rev Physiol 64:355-405. 